\title{
Nodule-Inducing Virus
}

National Cancer Institute

\section{Source}

National Cancer Institute. Nodule-Inducing Virus. NCI Thesaurus. Code C29902.

An exogenous, infectious mouse mammary tumor virus isolated from BALB/cNIV/Crg I

mice, thought to be derived from the endogenous low oncogenic mouse mammary

tumor virus found in C3Hf mice. (from Cancer Res. 1984 Oct;44(10):4333-6) 